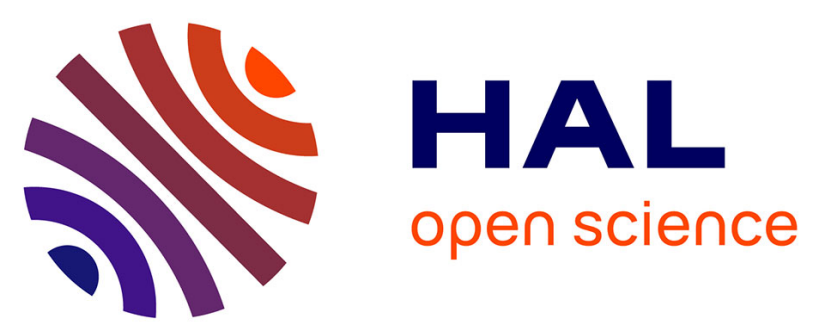

\title{
BEAM INDUCED VARIATIONS OF GaAs CATHODOLUMINESCENCE : EFFECT OF HYDROGEN AND DEFORMATION
}

A. Djemel, J. Castaing, Jacques Chevallier

\section{- To cite this version:}

A. Djemel, J. Castaing, Jacques Chevallier. BEAM INDUCED VARIATIONS OF GaAs CATHODOLUMINESCENCE : EFFECT OF HYDROGEN AND DEFORMATION. Journal de Physique Colloques, 1989, 50 (C6), pp.C6-178-C6-178. 10.1051/jphyscol:1989632 . jpa-00229663

HAL Id: jpa-00229663

https://hal.science/jpa-00229663

Submitted on 1 Jan 1989

HAL is a multi-disciplinary open access archive for the deposit and dissemination of scientific research documents, whether they are published or not. The documents may come from teaching and research institutions in France or abroad, or from public or private research centers.
L'archive ouverte pluridisciplinaire HAL, est destinée au dépôt et à la diffusion de documents scientifiques de niveau recherche, publiés ou non, émanant des établissements d'enseignement et de recherche français ou étrangers, des laboratoires publics ou privés. 
REVUE DE PHYSIQUE APPLIQUEE

Colloque C6, Supplément au $\mathrm{n}^{\circ} 6$, Tome 24 , Juin 1989

BEAM INDUCED VARIATIONS OF GaAS CATHODOLUMINESCENCE : EFFECT OF HYDROGEN AND DEFORMATION

A. DJEMEL, J. CASTAING and J. CHEVALLIER*

Laboratoire de Physique des Matériaux, CNRS, 1, Place A. Briand, F-92195 Meudon Cedex, France

"Laboratoire de physique des Solides, CNRS, 1, Place A. Briand; F-92195 Meudon Cedex, France

We use cathodoluminescence (CL) in a scanning electron microscope to study deep level recombination in semi-insulating GaAs. Two kinds of specimens were examined (i) as-grown crystals before and after hydrogenation, (ii) crystals deformed at high temperatures before and after hydrogenation. Hydrogen is introduced into the crystal using a R.F. hydrogen plasma $(T=$ $\left.240^{\circ} \mathrm{C}, \quad t=90 \mathrm{~min}.\right)$. A consequence of the introduction of hydrogen is a substantial increase of the light emitted under the electron beam, due to a passivation of deep level centers [1].

For a static beam, the CL intensity decays with time in as-grown crystals whereas it increases towards a maximum in the same hydrogenated crystals; for long time, the light emission finally decreases. In deformed crystals, and before hydrogenation, the CI intensity is time independent whereas after hydrogenation it decreases. The characteristics of the variations depend of the beam parameters (intensity, energy). The phenomena are due to defect redistributions, which alter the concentration of recombination centers, the defect mobility being enhanced by the electron bombardment. The similar variations have also been observed with a laser beam [2], [3].

[1] DJEMEL, A., CASTAING, J., CHEVALLIER, J., à paraître dans Revue Phys. Appl. $22, n^{\circ} 7$ (1988).

[2] GUIDOTTI, D., HASAN, E., HOVEL, H.J., ALBERT, M. App1. Phys. Lett. 50 (14) (1987) 912.

[3] RAJA, M.Y.A., BRUECK, S.R.J., OSINSKI, M., MCLNERNEY, J. Appl. Phys. Lett. 52 (8) (1988) 625 . 